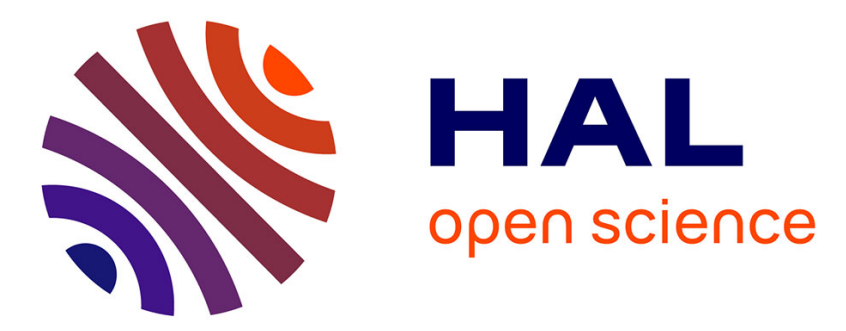

\title{
Detection of Merkel cell polyomavirus on environmental surfaces
}

Vincent Foulongne, Valérie Courgnaud, William Champeau, Michel Segondy

\section{To cite this version:}

Vincent Foulongne, Valérie Courgnaud, William Champeau, Michel Segondy. Detection of Merkel cell polyomavirus on environmental surfaces. Journal of Medical Virology, 2011, 83 (8), pp.1435. 10.1002/jmv.22110 . hal-00645107

\section{HAL Id: hal-00645107 https://hal.science/hal-00645107}

Submitted on 26 Nov 2011

HAL is a multi-disciplinary open access archive for the deposit and dissemination of scientific research documents, whether they are published or not. The documents may come from teaching and research institutions in France or abroad, or from public or private research centers.
L'archive ouverte pluridisciplinaire HAL, est destinée au dépôt et à la diffusion de documents scientifiques de niveau recherche, publiés ou non, émanant des établissements d'enseignement et de recherche français ou étrangers, des laboratoires publics ou privés. 


\section{Detection of Merkel cell polyomavirus on environmental surfaces}

\begin{tabular}{|r|l|}
\hline Journal: & Journal of Medical Virology \\
\hline Manuscript ID: & JMV-10-2235.R1 \\
\hline Wiley - Manuscript type: & Research Article \\
\hline Date Submitted by the \\
Author: & 28 -Jan-2011 \\
\hline Complete List of Authors: & $\begin{array}{l}\text { Foulongne, Vincent; Montpellier University hospital, Laboratory of } \\
\text { Virology } \\
\text { Courgnaud, Valérie; CNRS, IGMM } \\
\text { Champeau, William; Montpellier University Hospital, Laboratory of } \\
\text { Virology } \\
\text { Segondy, Michel; St-Eloi Hospital, Virology }\end{array}$ \\
\hline Keywords: & \begin{tabular}{l} 
MCPyV, Environment, Surface \\
\hline
\end{tabular} \\
\hline
\end{tabular}

\section{SCHOLARONE ${ }^{\text {M }}$}

Manuscripts 


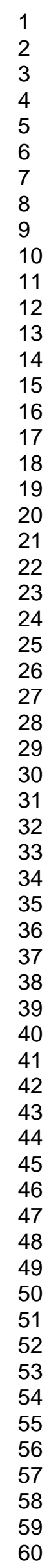

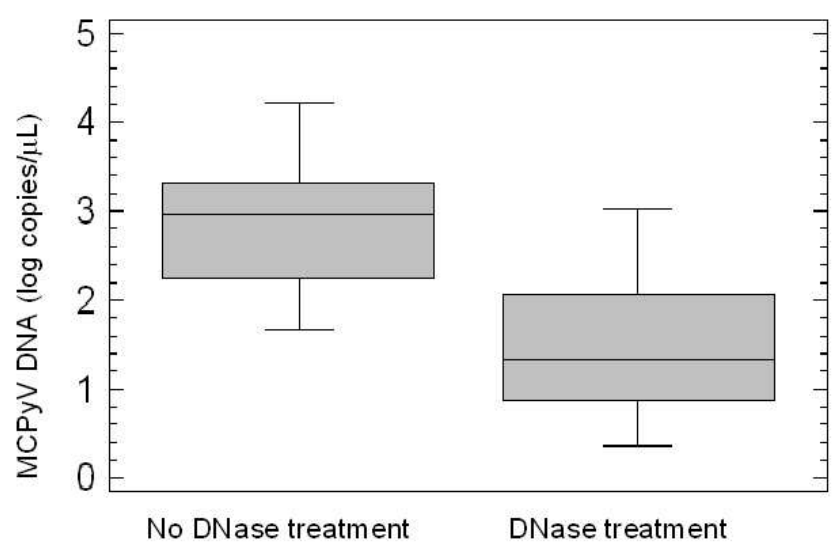

$254 \times 190 \mathrm{~mm}(96 \times 96$ DPI $)$ 
Table 1 : Detection of human DNA, MCPyV DNA on environmental surfaces

\begin{tabular}{|c|c|c|c|c|c|}
\hline \multirow{2}{*}{\multicolumn{2}{|c|}{ Environmental surfaces }} & \multirow{3}{*}{$\begin{array}{c}\text { Human DNA } \\
\text { Beta-globin target } \\
+\end{array}$} & \multirow{3}{*}{$\begin{array}{c}\text { LT3 target } \\
+\end{array}$} & \multirow{3}{*}{\multicolumn{2}{|c|}{$\begin{array}{cc} & \text { MCPyV } \\
\text { VP2/3 target } & \text { Viral load (copies/ng of human DNA) } \\
+ & 2,875 \\
\end{array}$}} \\
\hline & & & & & \\
\hline \multirow[t]{12}{*}{ Lab.1 } & Incubator handle 1 & & & & \\
\hline & Incubator handle 2 & + & + & + & 20,226 \\
\hline & Incubator handle 3 & + & + & + & 52 \\
\hline & Main door handle & + & + & + & 2,250 \\
\hline & Stairway banister & + & + & + & 2,588 \\
\hline & Door handle 1 & + & + & + & 611 \\
\hline & Door handle2 & + & + & + & 167 \\
\hline & Freezer handle & + & + & + & 100 \\
\hline & Lift keyboard & + & + & + & 1,600 \\
\hline & Hood working surface & + & - & - & na \\
\hline & Wall1 & - & - & - & na \\
\hline & Wall2 & + & - & - & na \\
\hline Lab.2 & Drink dispenser keybo & + & + & + & 2,941 \\
\hline
\end{tabular}




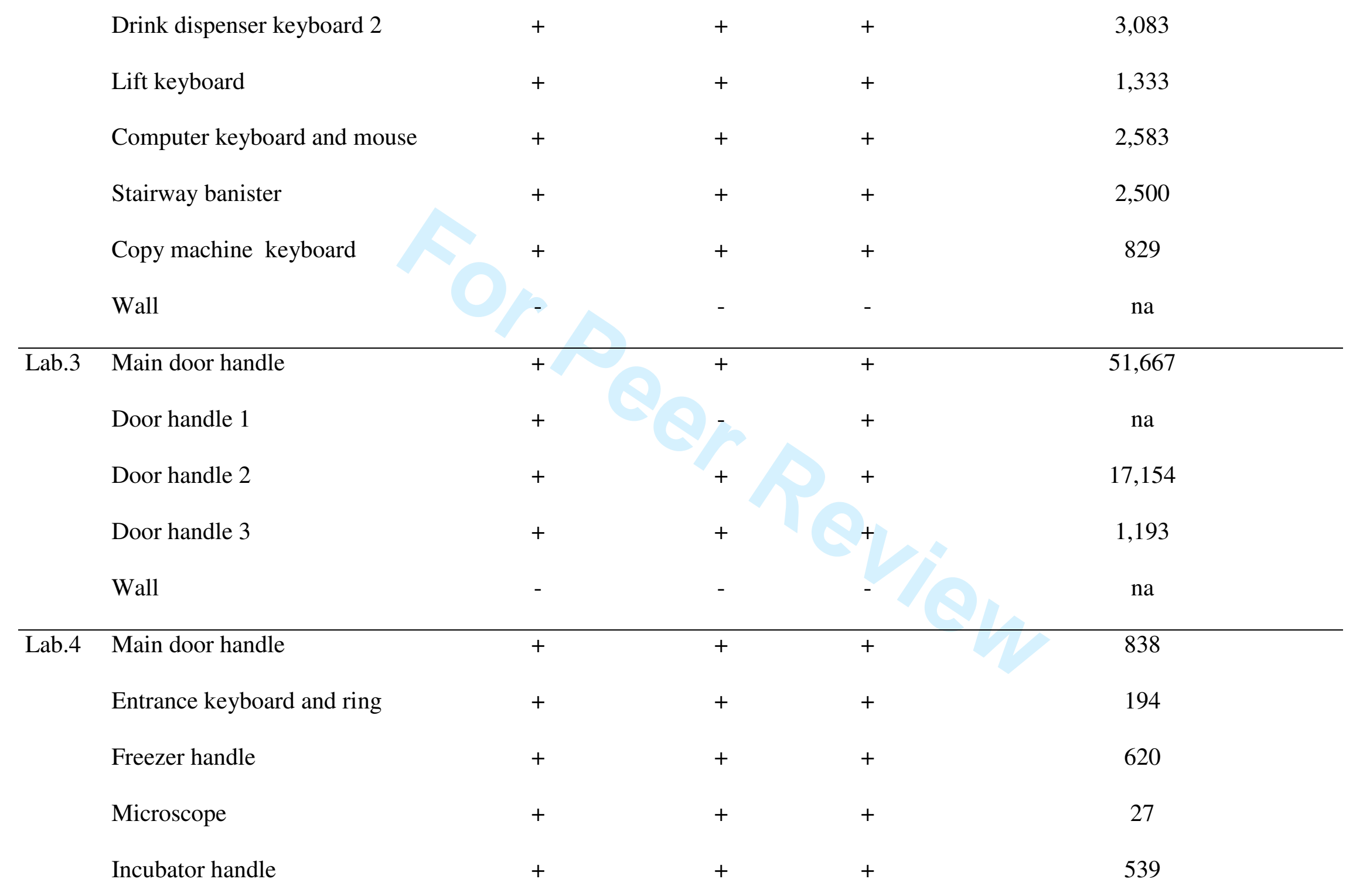




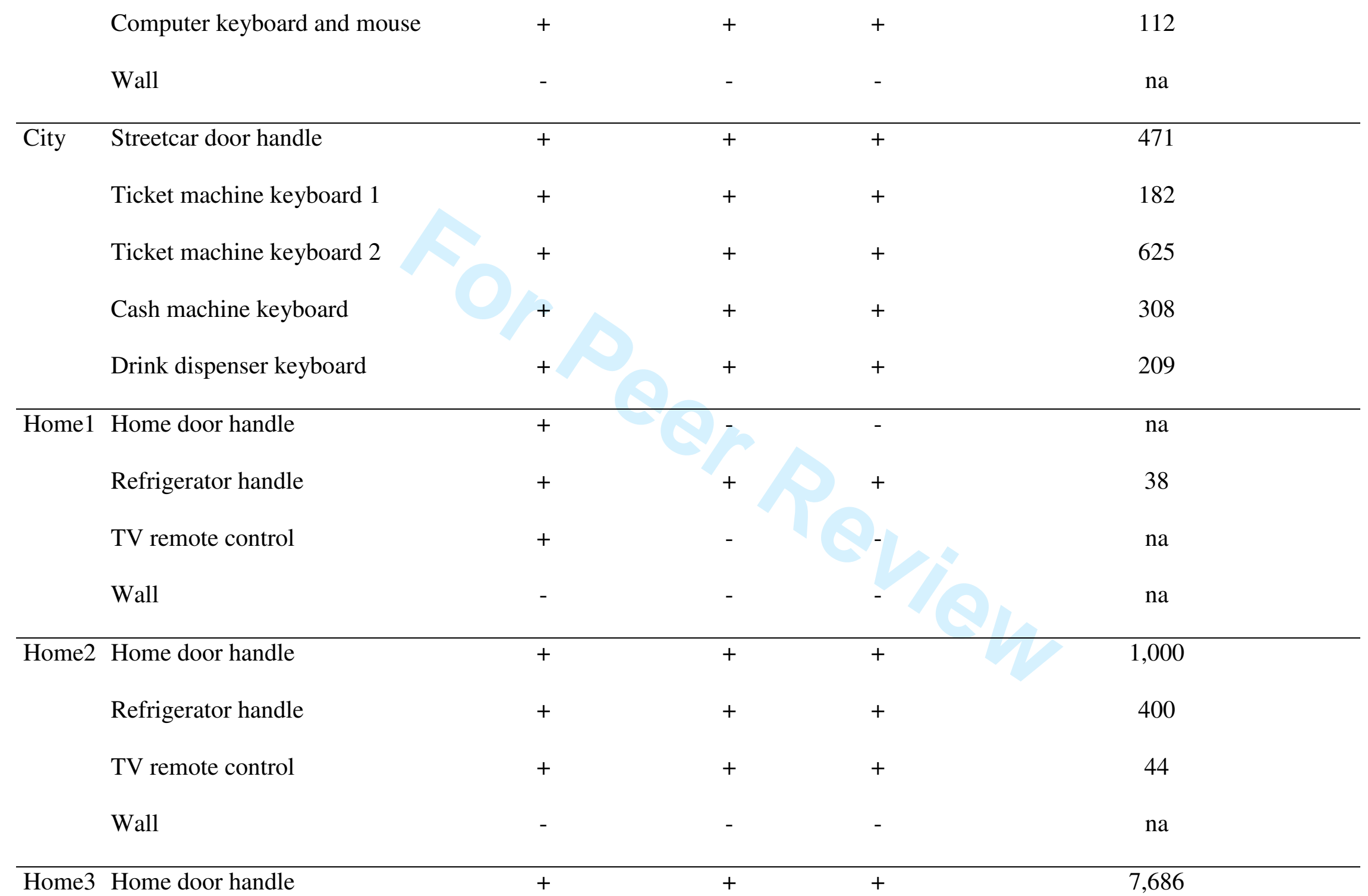




\begin{tabular}{|c|c|c|c|c|c|}
\hline & Refrigerator handle & + & + & + & 23,000 \\
\hline & TV remote control & + & + & + & 16,807 \\
\hline & Wall & + & + & + & 827 \\
\hline Home4 & Home door handle & + & + & + & 172 \\
\hline & Refrigerator handle & + & + & + & 28 \\
\hline & TV remote control & + & + & + & 325 \\
\hline & Wall & - & - & - & na \\
\hline Home5 & Home door handle & + & - & + & na \\
\hline & Refrigerator handle & + & - & + & na \\
\hline & TV remote control & + & - & + & na \\
\hline & Wall & - & - & - & na \\
\hline Home6 & Home door handle & + & + & + & 7 \\
\hline & Refrigerator handle & + & - & - & na \\
\hline & TV remote control & + & - & - & na \\
\hline & Wall & - & - & - & na \\
\hline
\end{tabular}

na: not applicable 
1 Title

\section{Detection of Merkel cell polyomavirus on environmental surfaces}

3

4 Shortened title

$5 \quad$ MCPyV on environmental surfaces

6

7

8 Vincent Foulongne ${ }^{1,2^{*}}$, Valérie Courgnaud ${ }^{3}$, William Champeau ${ }^{1}$, and Michel Segondy ${ }^{1,2}$ 9

10 Affiliations:

$11{ }^{1}$ Department of Biology and Pathology, Laboratory of virology, Montpellier University 12 Hospital Montpellier, France,

$13 \quad 2$ INSERM U.1058, Montpellier, France

$14{ }^{3}$ Institute of Molecular Genetics, CNRS UMR5535, Montpellier, France.

15

16 Key words: MCPyV, environment, surfaces

17

18

19

$20 *$ Corresponding author:

21 Vincent Foulongne, Laboratory of Virology, Hôpital St-Eloi, 34295 Montpellier Cedex5,

22 France.

23 Tel.: +33 467337 127; fax: +33 467337793

24 E-mail address: v-foulongne@chu-montpellier.fr 


\section{Abstract}

2 The Merkel cell polyomavirus (MCPyV) is a human virus identifed recently which is

3 associated with the Merkel cell carcinoma. This virus is also detected frequently in the skin of

4 healthy individuals. The presence of MCPyV has been investigated on environmental surfaces

5 in contact with human skin. Various surfaces in 4 laboratories, public places, and individual

6 homes were swabbed. Human DNA and MCPyV DNA were detected in swabs by real-time

7 PCR. MCPyV DNA levels were measured before an after DNase treatment in a set of 12

8 MCPyV DNA-positive samples. A total of 60 environmental surface samples were collected.

9 Fifty-one (85.0\%) were positive for human DNA detection and $45(75.0 \%)$ were positive for

10 MCPyV DNA detection. All samples positive for MCPyV DNA were positive for human

11 DNA detection. After DNase treatment, a $1.3 \log$ decrease in MCPyV DNA level was

12 observed indicating that about $5 \%$ of viral DNA is protected from DNase degradation and

13 might be associated with infectious virus. These results indicate that MCPyV DNA may be

14 detected on environmental surfaces in contact with human skin. Detection of viral DNA might

15 reflect the presence of infectious viral particles and transmission from environmental source

16 to humans cannot be ruled out. 


\section{Introduction}

2 The Merkel cell polyomavirus $(\mathrm{MCPyV})$ is a novel human polyomavirus discovered in a rare

3 and aggressive neuroendocrine skin cancer, the Merkel cell carcinoma [Feng et al., 2008].

4 Subsequent studies have confirmed that, unlike the other human polyomaviruses, MCPyV

5 has an oncogenic potential [Shuda et al., 2008; Sastre-Garau et al., 2009; Shuda et al., 2009].

6 However, seroepidemiological studies indicate that MCPyV circulates widely in the human

7 population [Kean et al., 2009], and a widespread distribution of MCPyV in the human

8 population was suggested recently by studies reporting a frequent detection of $\mathrm{MCPyV}$ in

9 cutaneous swabs from healthy adults [Foulongne et al., 2010b; Scholwalter et al., 2010;

10 Wieland et al., 2010]. These studies indicate that MCPyV causes a persistent asymptomatic

11 infection of the most superficial layers of the epidermis. The route of transmission of MCPyV

12 remains uncertain. Possible respiratory or fecal-oral routes of transmission have been

13 suggested, supported by the detection of the virus in respiratory secretions, in saliva or in

14 urban sewages [Bialasiewicz et al., 2009; Loyo et al., 2010; Bofill-Mass et al., 2010]. The

15 high rate of detection of MCPyV DNA in the superficial skin might indicate a cutaneous route

16 of transmission through contact with human skin or contaminated surfaces. The aim of the

17 present study was to investigate the contamination of environmental surfaces by MCPyV.

19 Material and methods

20 Environment samples

21 Environmental surfaces were swabbed by laboratory workers wearing gloves, using cotton-

22 tipped swabs soaked in phosphate buffer saline (PBS). Samples were collected from various

23 surfaces located in the laboratory involved directly in the study (lab.1), in three other

24 laboratories not involved in MCPyV detection, in public environment within the Montpellier

25 city, and in six individual homes from lab. 1 workers. Swabs were transported at room 
1 temperature and conserved at $-20^{\circ} \mathrm{C}$ until analyzed. Surfaces that were swabbed were chosen

2 depending on the environment, with a particular focus on objects with frequent contact with

3 human skin. They were various handles (doors, refrigerators, freezers, incubators), keyboards

4 (lifts, computers, drink dispensers, cash dispensers, ticket machines) and stair banisters. In

5 each environment, surfaces not exposed to contact with human skin, such as walls sampled

6 around $2 \mathrm{~m}$ off the ground, or hood working surfaces in the laboratories, were swabbed as

7 controls (Table 1).

\section{DNA extraction and DNase treatment}

10 Swabs were suspended in $600 \mu \mathrm{L}$ of PBS and DNA was extracted from $200 \mu \mathrm{L}$ of the

11 suspension with the EasyMag nucleic acid extractor (BioMérieux, Marcy l'Etoile, France).

12 For DNase treatment, the residual suspension was separated into two $200 \mu \mathrm{L}$ fractions. The

13 10X DNase buffer was added and 2 IU of DNase (New England Biolabs, Ipswich, MA) was

14 added in one fraction, the other being completed with the corresponding volume of PBS. Both

15 fractions were incubated $1 \mathrm{~h}$ at $37^{\circ} \mathrm{C}$ and heated $10 \mathrm{~min}$ at $95^{\circ} \mathrm{C}$ for DNase inactivation prior

16 DNA extraction. The elution volume was $50 \mu \mathrm{L}$, and $5 \mu \mathrm{L}$ of eluate was used for subsequent

17 PCR assays. A non-used swab processed under the same conditions was included in each run

18 as negative control.

19

20 MCPyV and human DNA quantitation

21 MCPyV DNA was detected and quantified by real-time PCR in the large T-antigen coding

22 region as previously described [Foulongne et al., 2010a]. Positive results were confirmed by a 23 second real-time PCR targeting the VP2/3 region [Bialasiewicz et al., 2009], located outside 24 the regions amplified previously in the laboratory. 
1 Total human DNA levels in samples were measured using the LightCycler control DNA kit

2 (Roche Diagnostics, Meylan, France) and results were expressed as MCPyV DNA copies/ng

3 of human DNA or as MCPyV copies/ $\mu \mathrm{L}$ for sample comparison when DNase treatment was

4 applied.

5

\section{$6 \quad$ Results}

7 A total of 60 surface samples were collected. Fifty-one (85\%) were positive for human DNA detection and 45 (75\%) were positive for MCPyV DNA detection (Table 1). MCPyV DNA positivity was $81 \%, 100 \%$ and $67 \%$ for samples collected in laboratories, city and individual homes, respectively $(P=0.2)$. Human DNA levels in positive samples ranged from 5.0 to 2,700 pg/ $\mu \mathrm{L}$ (median, $25 \mathrm{pg} / \mu \mathrm{L}$ ). All MCPyV-positive samples were positive for human DNA detection. Among the 11 samples collected on walls, $9(81.8 \%)$ were negative for human DNA and 10 (90.1\%) were negative for MCPyV DNA.

The median MCPyV DNA level was 2.8 log copies/ng of human DNA (range 0.8-5.2 log copies/ng of human DNA). No correlation was observed between MCPyV DNA and human DNA levels $\left(\mathrm{R}^{2}=0.007\right)$.

A set of 12 samples positive for MCPyV DNA were processed in parallel with and without DNase treatment. Median human DNA level in these samples was $97 \mathrm{pg} / \mu \mathrm{L}$ (range 10-762 $\mathrm{pg} / \mu \mathrm{L}$ ). Median viral DNA load in these samples was $2.45 \log$ copies/ $\mu \mathrm{L}$ (range, 1.6-4.2 log copies $/ \mu \mathrm{L})$. After DNase treatment, MCPyV DNA was still detectable in 10 samples with a median level that decreased to $1.14 \log$ copies/ $\mu \mathrm{L}$ (range $0.7-3.8 \log$ copies $/ \mu \mathrm{L}$ ), representing a decrease of $1.3 \log$ in MCPyV DNA level and indicating that about $5 \%$ of viral DNA was protected from DNase degradation (Fig.1). In contrast, in the same conditions human DNA became undetectable after DNase treatment of the samples. 


\section{Discussion}

2 Polyomaviruses are non-enveloped, double stranded DNA viruses that may persist in various

3 environmental media [Bofill-Mass et al., 2001; Jiang et al., 2009]. Results from the present

4 study indicate that MCPyV DNA is detected with a high frequency on the environmental

5 surfaces.

6 High viral DNA levels despite low human DNA levels might be explained by the fact that the

7 cutaneous viruses are abundantly present in the most superficial layers of the epidermidis, the

8 stratum corneum, composed mainly of dead and apoptotic cells with genomic DNA

9 fragmented by host cells DNases that might not affect viral DNA. This might also explain

10 why levels of MCPyV DNA, as normalized to human DNA, in environment samples were

11 higher than those reported previously in human skins specimens [Foulongne et al., 2010b].

12 The relative high level of MCPyV DNA normalized to human DNA on environmental

13 surfaces might be explained also by an accumulation of viral DNA more resistant to

14 degradation than human DNA. This cumulative effect may also explain the highest, although objects sampled were more prone to be handled by many people as compared with those sampled in individual homes.

18 Infectivity of the viruses detected on environmental surfaces could not be investigated since

19 neither animal nor cellular models are available. However, viral MCPyV DNA remained 20 detectable after DNase treatment prior to nucleic acid extraction. A major proportion of the 21 viral DNA was digested by the DNase, suggesting that this viral DNA is not protected by an 22 entire viral capsid. However, the about $5 \%$ of viral DNA that remained protected from 23 degradation might represent encapsidated DNA belonging to potentially infectious virions. 24 This is in accordance with a recent study reporting the cutaneous shedding of MCPyV and 25 novel polyomaviruses in the form of virions [Scholwalter et al., 2010]. Culture-independent 
1 methods are widely used to monitor levels of environmental contamination with

2 microorganisms and recent studies have demonstrated that viral genetic markers from both

3 viral particles and naked viral genome persist for a longer time than infectious virions in

4 environment [Walters et al., 2009]. However, the infectious potential of the viral genomic

5 material detected on the environmental surfaces can not be excluded.

6 Numerous environmental media are contaminated with polyomaviruses. This was described

7 for SV40, isolated from waste in monkeys' cage [Bofill-Mass et al., 2004] as well as for the

8 two human JC and BK polyomaviruses that could be easily detected in urban sewage samples

9 [Bofill-Mass et al., 2001; Hundesa et al., 2006]. Recent findings of MCPyV DNA in various 10 samples like saliva [Loyo et al., 2010], respiratory samples [Bialasiewicz et al., 2009] as well 11 as in sewage samples [Bofill-Mass et al., 2010] are consistent with the ubiquitous MCPyV 12 shedding. Results obtained in this study reinforce this hypothesis.

13 In conclusion, the present study indicates that MCPyV DNA may be detected on virtually all 14 the environmental surfaces in contact with human skin. Detection of viral DNA might reflect 15 the presence of infectious viral particles and transmission from environmental source to 16 humans cannot be ruled out. 
References

2

Bialasiewicz S, Lambert SB, Whiley DM, Nissen MD, Sloots TP. 2009. Merkel cell polyomavirus DNA in respiratory specimens from children and adults. Emerg Infect Dis 15:492-494.

Bofill-Mas S, Abinana-Gimenez N, Pipkin PA, Minor PD, Girones R. 2004. Isolation of SV40 from the environment of a colony of cynomolgus monkeys naturally infected with the virus. Virology 330:1-7.

Bofill-Mas S, Rodriguez-Manzano J, Calgua B, Carratala A, Girones R. 2010. Newly described human polyomavirus Merkel cell, KI and WU are present in urban sewage and may represent potential environmental contaminants. Virol J 7:141.

Bofill-Mass S, Formiga-Cruz M, Clemente-Casares P, Calafell F, Girones R. 2001. Potential transmission of human polyomaviruses through the gastrointestinal tract after exposure to virions or viral DNA J Virol 75:10290-10299.

Feng H, Shuda M, Chang Y, Moore PS. 2008. Clonal integration of a polyomavirus in human Merkel cell carcinoma. Science. 319:1096-1100.

Foulongne V, Dereure O, KlugerN, Molès JP, Guillot B, Segondy M. 2010 a. Merkel cell polyomavirus DNA detection in lesional and non-lesional skin from patients with Merkel cell carcinoma or other skin diseases. Br J Dermatol 162:59-63.

Foulongne V, Kluger N, Dereure O, Mercier G, Moles JP, Guillot B, Segondy M. 2010 b. Merkel cell polyomavirus in cutaneous swabs. Emerg Infect Dis 16:685-7.

Hundesa A, Maluquer de Motes C, Bofill-Mas S, Albinana-Gimenez N, Girones R. 2006. Identification of human adenoviruses and polyomaviruses for determination of sources of fecal contamination in the environment. Appl Environ Microbiol 72:7886-93. 
1 Jiang M, Abend JR, Johnson SF, Imperiale MJ. 2009. The role of polyomaviruses in

2

3

4

5

6

7

8

9

10

11

12

13

14

15

16 human disease. Virology 384:266-73.

Kean JM, Rao S, Wang M, Garcia RL. 2009. Seroepidemiology of human polyomaviruses. PloS Pathogen 5(3):e1000363.

Loyo M, Guerrero-Preston R, Brait M, Hoque MO, Chuang A, Kim MS, Sharma R, Liégois NJ, Koch WM, Califano JA, Westra WH, Sidransky D. 2010. Quantitative detection of Merkel cell virus in human tissues and possible mode of transmission. Int J Cancer 126:2991-6.

Sastre-garaud X, Peter M, Avril MF, Laude H, Couturier J, Rozenberg F, Almeida A, Boitier F, Carlotti A, Couturaud B, Dupin N. 2009. Merkel cell carcinoma of the skin: pathological and molecular evidence for a causative role of MCV in oncogenesis. J Pathol 218:48-56.

Schowalter RM, Pastrana DV, Pumphrey KA, Moyer AL, Buck CB. 2010. Merkel cell polyomavirus and two previously unknown polyomaviruses are chronically shed from human skin. Cell Host \& Microbe 7:509-515.

Shuda M, Arora R, Kwun HJ, Sarid R, Fernandez-Figueras MT, Tolstov Y, Gjoerup O, Mansukhani MM, Swerdlow SH, Chaudhary PM, Kirkwood JM, Nalesnik MA, Kant JA, Weiss LM, Moore PS, Chang Y. 2009. Human Merkel cell polyomavirus infection I. MCV T antigen expression in Merkel cell carcinoma, lymphoïd tissues and lymphoïd tumors. Int J Cancer 125:1243-1249.

Shuda M, Feng H, Kwun HJ, Rosen ST, Gjoerup O, Moore PS, Chang Y. 2008. T antigen mutations are a human tumor-specific signature for Merkel cell polyomavirus. Proc Natl Acad USA 105:16272-16277. 
1

4

5

6

7

8

9

10

11

12

13

14

15

16

17

18

19

20

21

22

23

24

25

26

27

28

29

30

31

32

33

34

35

36

37

38

39

40

41

42

43

44

45

46

47

48

49

50

51

52

53

54

55

56

57

58

59

60

1 Walters SP, Yamahara KM, Boehm AB. 2009. Persistence of nucleic acid markers of

2 health-relevant organisms in seawater microcosms: Implications for their use in

3 assessing risk in recreational waters. Water Research 43:4929-39.

4 Wieland U, Mauch C, Kreuter A, Krieg T, Pfister H. 2009. Merkel cell polyomavirus DNA in persons without Merkel cell carcinoma. Emerg Infect Dis 15:1496-8. 


\section{$1 \quad$ Figure 1}

2 Effect of DNase treatment on MCPyV DNA level. Data are presented as box and whiskers

3 plots, where the boxes represent the interquartile range, the lines within the boxes represent

4 the median value, and the whiskers represent 1.5 times the interquartile range.

5

6 